Review

\title{
The cytokinesis-block micronucleus (CBMN) assay in human populations exposed to styrene: A systematic review and meta-analysis
}

\author{
Solange Costa ${ }^{\mathrm{a}, \mathrm{b}, *}$, Marcello Ceppi $^{\mathrm{c}}$, Carla Costa $^{\mathrm{a}, \mathrm{b}}$, Susana Silva $^{\mathrm{a}}$, Cristiana Pereira ${ }^{\mathrm{a}, \mathrm{b}}$, \\ Blanca Laffon ${ }^{\mathrm{d}}$, Stefano Bonassi ${ }^{\mathrm{e}, \mathrm{f}}$, João Paulo Teixeira ${ }^{\mathrm{a}, \mathrm{b}}$ \\ a National Institute of Health, Environmental Health Department, Rua Alexandre Herculano, 321, 4000-055 Porto, Portugal \\ ${ }^{\mathrm{b}}$ EPIUnit - Institute of Public Health, University of Porto, Rua das Taipas, 135, 4050-600 Porto, Portugal \\ c Unit of Clinical Epidemiology, IRCCS AUO San Martino-IST, Largo Rosanna Benzi 10, 16132 Genoa, Italy \\ d DICOMOSA Group, Department of Psychology, Area of Psychobiology, Universidade da Coruña, Research Services Building, Campus Elviña s/n, 15071 A \\ Coruña, Spain \\ e Unit of Clinical and Molecular Epidemiology, IRCCS San Raffaele Pisana, Via di Val Cannuta, 247, 00166 Roma, Italy \\ ${ }^{\mathrm{f}}$ Department of Human Sciences and Quality of Life Promotion, San Raffaele University, Via di Val Cannuta, 247, 00166 Roma, Italy
}

\section{A R T I C L E I N F O}

\section{Article history:}

Received 27 December 2015

Received in revised form 15 June 2016

Accepted 18 June 2016

Available online 23 June 2016

\section{Keywords:}

Styrene

Human exposure

Micronuclei

CBMN assay

Meta-analysis

Systematic review

\begin{abstract}
A B S T R A C T
Styrene is a building-block of several compounds used in a wide array of materials and products. The most important human exposure to this substance occurs in industrial settings, especially among reinforced-plastics industry workers. The effect of occupational exposure to styrene on cytogenetics biomarkers has been previously reviewed with positive association observed for chromosomal aberrations, and inconclusive data for the micronucleus assay. Some limitations were noted in those studies, including inadequate exposure assessment and poor epidemiological design. Furthermore, in earlier studies micronuclei frequency was measured with protocols not as reliable as cytokinesis-block micronucleus (CBMN) assay. Aim of the present systematic review and meta-analysis is to investigate genomic instability and DNA damage as measured by the CBMN assay in lymphocytes of subjects exposed to styrene. A total of 11 studies published between 2004 and 2012 were included in the meta-analysis encompassing 479 styrene-exposed workers and 510 controls. The quality of each study was estimated by a quality scoring system which ranked studies according to the consideration of major confounders, exposure characterization, and technical parameters. An overall increase of micronuclei frequencies was found in styrene-exposure workers when compared to referents (meta-MR 1.34; 95\% CI 1.18-1.52), with significant increases achieved in six individual studies. The consistency of results in individual studies, the independence of this result from major confounding factors and from the quality of the study strengthens the reliability of risk estimates and supports the use of the CBMN assay in monitoring genetic risk in styrene workers.
\end{abstract}

(๔) 2016 Elsevier B.V. All rights reserved.

\section{Contents}

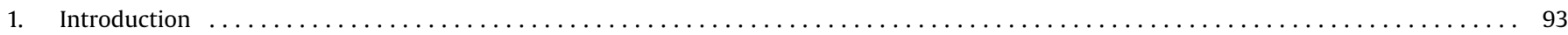

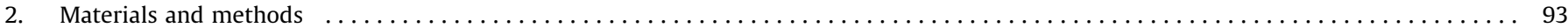

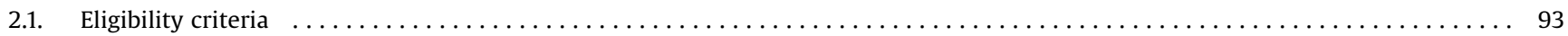

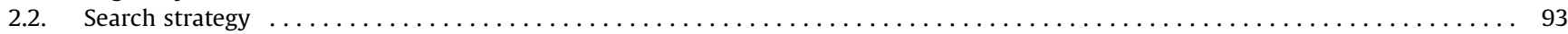

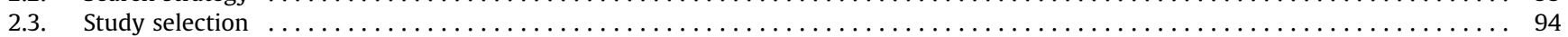

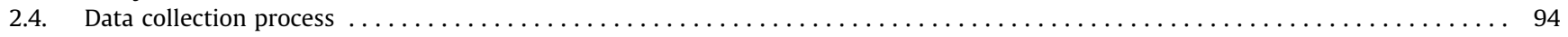

\footnotetext{
* Corresponding author at: National Institute of Health, Environmental Health

Department, Rua Alexandre Herculano, 321, 4000-055 Porto, Portugal.

E-mail address: solange.costa2@gmail.com (S. Costa).
} 


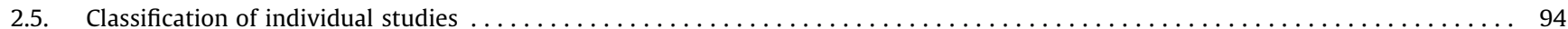

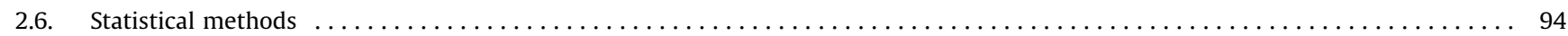

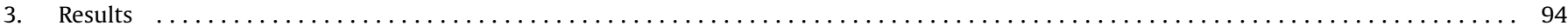

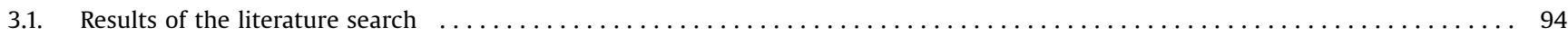

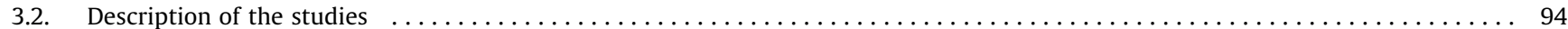

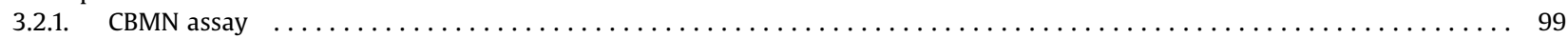

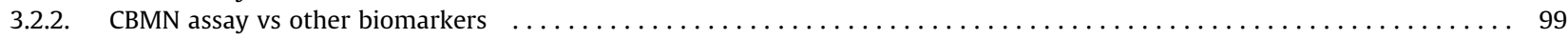

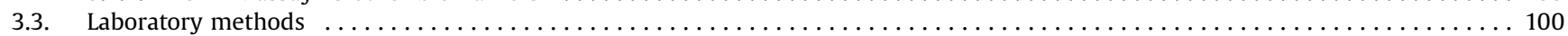

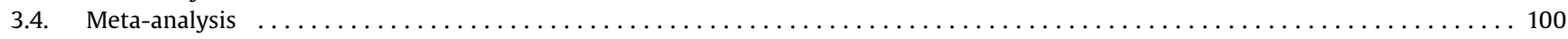

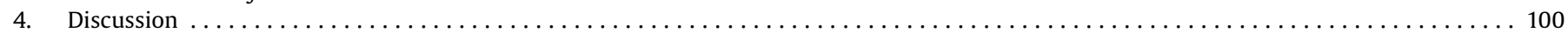

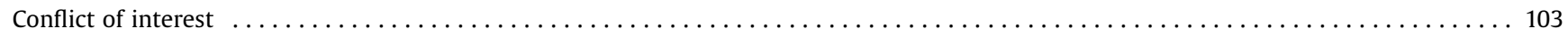

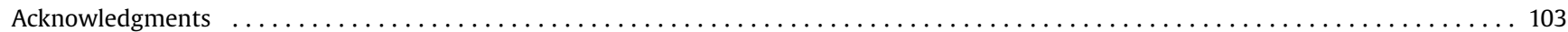

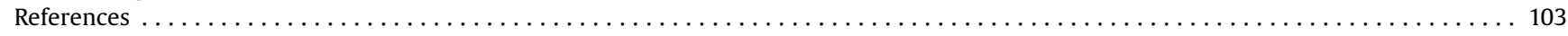

\section{Introduction}

Styrene is a high-volume production chemical precursor to polystyrene and several other copolymers used extensively in the production of synthetic rubber, plastic, insulation, fiberglass, automobile components, food containers and latex paints [1]. The highest level of human exposure occurs in occupational settings during industrial synthesis and manufacturing of styrenecontaining products. According to literature, subjects more heavily exposed are reinforced-plastics industry workers, and to a lesser extent styrene-butadiene rubber industry workers [2]. In these settings, absorption of styrene occurs mainly through inhalation and, to a minor extent, via skin contact [3]. Although environmental exposure typically occurs at much lower levels than occupational exposure, general population is exposed through mainstream cigarette smoke, motor vehicle exhaust, and newly installed carpets containing styrene-rubber latex adhesive [1]. The first step of styrene metabolism is usually the cytochrome P450 (CYP)-mediated oxidation to styrene-7,8-oxide (SO) an electrophilic intermediate capable of binding covalently to macromolecules and considered to be directly responsible for the genotoxic effects of styrene [3]. SO can be detoxified by glutathione conjugation or converted to styrene glycol by microsomal epoxide hydrolase and excreted in urine in the form of mandelic acid (MA) and phenylglyoxylic acid (PGA) (main route) [1].

Recently the U.S. National Institute of Environmental Health Sciences listed styrene as reasonably anticipated to be a human carcinogen based on credible but limited evidence of carcinogenicity in epidemiologic studies, on sufficient evidence of carcinogenicity in animals, and on convincing evidence that styrene is genotoxic in exposed humans [2]. The evidence comes mainly from occupational-cohort studies of reinforced-plastics workers in Europe and U.S., linking styrene exposure to an increase frequency of lymphohematopoietic, esophageal, and pancreatic cancers [4-6]. The proposed mechanisms for the carcinogenicity of styrene include both genotoxic and epigenetic pathways [2]. The cytokinesis-block micronucleus (CBMN) assay in human lymphocytes has become one of the most widely used methods for measuring chromosomal damage in human cells in vitro and in vivo $[7,8]$. In human biomonitoring studies CBMN has been used for decades as a standard biodosimetry assay to assess the genotoxic effects of exposure to chemical compounds in occupational and environmental settings. The assay is also applied in in vitro genetic toxicology to test new compounds for regulatory purposes [9]. Since it represents a measure of both chromosome breakage and chromosome loss, an increased frequency of micronucleated cells can reflect exposure to genotoxic agents with clastogenic or aneugenic modes of action [10]. Furthermore, prospective studies evaluating large cohorts of disease-free subjects revealed that an increase in micronuclei frequency in peripheral blood lymphocytes was associated with an increased risk of cancer, at the population level [11,12], providing suggestive evidence that micronuclei formation is associated with early events in carcinogenesis.

Styrene has been shown to induce single strand breaks as well as cytogenetic damage and aneuploidy in several cell systems in vitro [13] and in lymphocytes of exposed workers [3,14,15]. Since the first report in 1977, a total of twenty-five studies were published measuring the frequency of micronuclei in lymphocytes of workers exposed to styrene, with both positive and negative outcomes. Few groups have critically reviewed the data available on human studies, particularly in relation to cytogenetic endpoints $[3,13,15,16]$. Compelling evidence of a positive association between styrene exposure levels and the frequency of chromosomal aberrations was found, as for micronuclei frequency the association remains inconclusive $[3,13,15]$. The major weaknesses found were the limited sample size, the inadequate exposure assessment, the poor epidemiological design or inappropriate statistical analysis $[15,16]$ mostly observed in earlier studies. Some of the studies included in the abovementioned reviews did not used CBMN assay using other protocols which did not allow a reliable identification of once-divided cells and thus expression of DNA damage as micronuclei. Others were performed in the early stages of CBMN assay when methods and scoring criteria were not well established. Since last meta-analysis study [15] around twelve cross-sectional studies on occupational exposure to styrene were published using similar CBMN protocols. Hence, a critical review of the new available data is needed for a better understanding of styrene genotoxicity and potential mechanism of carcinogenicity, as well as the role of micronuclei formation as an early cancer risk biomarker of human in vivo chemical exposure, particularly to styrene. The aim of the present study was to retrieve, review and synthesise published evidence in order to assess the sensitivity of the CBMN assay to measure DNA damage in lymphocytes of subjects exposed to styrene.

\section{Materials and methods}

This systematic review follows the methodology described in the PRISMA statement [17].

\subsection{Eligibility criteria}

Eligible for the inclusion in the present review were all studies on human in vivo exposure to styrene in which DNA damage was evaluated in lymphocytes by the CBMN assay.

\subsection{Search strategy}

Studies were identified by using the MedLine/PubMed database (National Library of Medicine, National Institutes of Health, Bethesda, MD, USA; http://www.ncbi.nlm.nih.gov/pubmed/). 
The terms 'micronucleus' or 'micronuclei' were used as subject heading associated to 'styrene exposure' using AND operator. The search filter 'Humans' was used to retrieved studies conducted only in human subjects. Further search using the key heading 'micronuclei and styrene exposure' was performed through Research Gate and two additional publications on human exposure were identified from this source.

\subsection{Study selection}

All retrieved studies were reviewed and assessed by two coauthors (SC and JPT) for inclusion in the present analysis. Only in vivo human exposure studies reporting a fully detailed description of the experimental protocol used for the CBMN test were included in the meta-analysis. After first selection, a number of publications were discarded because of inadequate study design, relevant coexposure to other(s) genotoxic chemical(s) or insufficient data reporting.

\subsection{Data collection process}

All studies complying with inclusion criteria were crosssectional studies of populations occupationally exposed to styrene in the workplace. For each study, the following information was collected: number of styrene-exposed workers and controls; type of industry/factory; controls origin; styrene exposure indicators and measurements, namely air-exposure and/or body fluids levels (biomarkers of exposure); period of body fluids collection (begin or end of shift); data/use of personal protective equipment (PPE); information on co-exposure; years of employment (duration of exposure); lymphocyte micronuclei frequencies expressed as number of micronucleated binucleated cells (MNed) and/or frequency of binucleated cells with micronuclei (MNi). Data on micronuclei frequencies in other tissues, MN-FISH (fluorescence in situ hybridization) assay and other effect biomarkers were also listed when available.

\subsection{Classification of individual studies}

A quality score (QS) was calculated for each of the selected studies to evaluate the standard of study designs. Studies were classified according to the following predefined parameters: (i) number of subjects in control group, (ii) number of subjects in exposed group (iii) age-matching, (iv) gender-matching, (v) nutritional status-matching, (vi) smoking status-matching, (vii) alcohol intake-matching (viii) styrene exposure assessment and, (ix) number of cells scored per subject. Each parameter scored 1 to a maximum of 3 points based on reported data and matching status (not-matched, partly and perfectly matched). Not-matched ( 1 point) was considered when factors were significantly different between groups or data was not collected and, partly-matched ( 2 points) when factors were not statistically different between groups even though they were not perfectly matched (3 points). Styrene exposure assessment was scored regarding the method used: by questionnaire ( 1 point), air-exposure levels ( 2 points) or measurement in body fluids ( 3 points). The maximum and minimum of total QS possible is 27 and 9 respectively.

\subsection{Statistical methods}

We computed the Mean Ratio $\left(\mathrm{MR}_{\mathrm{i}}\right)$ for each study as follows: $\mathrm{MR}_{\mathrm{i}}=[\mathrm{MN}$ mean (exposed) $] /[\mathrm{MN}$ mean (controls) $]$

This measure of effect is relatively independent from the absolute values of the means, reduces the extent of interlaboratory variability, and increases the comparability across the studies considered.

To estimate an overall measure of the effect we computed a weighted mean of the $M R_{i} s$ (meta-MR) with weights related to the variance of $M_{\mathrm{i}}$ in each study. To stabilize the within-study variances, we performed the calculation transforming the $\mathrm{MR}_{\mathrm{i}}$ in its natural logarithm $(\ln )$. The variance of $\ln \left(\mathrm{MR}_{\mathrm{i}}\right)$ is, approximately,

$\operatorname{Var}\left[\ln \left(\mathrm{MR}_{\mathrm{i}}\right)\right]=\left[\operatorname{Var}\left(\mathrm{mp}_{\mathrm{i}}\right) / \mathrm{mp}_{\mathrm{i}}{ }^{2}\right]+\left[\operatorname{Var}\left(\mathrm{mc}_{\mathrm{i}}\right) / \mathrm{mc}_{\mathrm{i}}{ }^{2}\right]$

where $m p_{i}$ and $m_{c}$ are the mean of micronucleus (MN) frequency of exposed and control groups, respectively, and $\operatorname{Var}\left(\mathrm{mp}_{\mathrm{i}}\right)$ and $\operatorname{Var}$ $\left(\mathrm{mc}_{\mathrm{i}}\right)$ are the corresponding variances.

The analysis was carried out using the random effects model [18], a special form of linear regression model,

$\ln \left(\mathrm{MR}_{\mathrm{i}}\right)=\boldsymbol{\mu}+\boldsymbol{\alpha} X_{\mathbf{i}}+\boldsymbol{\beta}_{\mathbf{i}}+\boldsymbol{\tau}_{\mathrm{i}}$

where the parameter $\mu$ is $\ln ($ meta-MR); $\alpha$ is a vector of unknown parameters representing the effects of the $X_{\mathrm{i}}$ covariates; the parameter $\beta_{i}$ is the residual of the ith-study from the overall value $\mu$ and its variance $\left(\Delta^{2}\right)$ is estimated from the data; $\boldsymbol{\tau}_{i}$ is the error in estimating $\ln \left(\mathrm{MR}_{\mathrm{i}}\right)$ in repeated samples from the same population to which the ith-study belongs; the variance of $\boldsymbol{\tau}_{\mathrm{i}}$ is assumed to be known and estimated by $\operatorname{Var}\left[\ln \left(\mathrm{MR}_{\mathrm{i}}\right)\right]$.

This model allowed to estimate the amount of the variability between studies $\left(\Delta^{2}\right)$ and accordingly provided suitable estimates of the standard errors of the parameters.

The differences between exposed and controls in mean age and in the percentages of males and smokers of each study were analysed as possible confounders of the meta-MR estimate through a meta-regression. In addition, the association with work-related variables was also tested.

To verify if some study strongly influenced the estimate of the meta-MR a sensitivity analysis, excluding the studies one at the time and recomputing the meta-MR, was performed.

As far as publication bias is concerned, we explored the possibility that only selected studies were published by applying the Egger' test [19] and through the visual inspection of the funnel plot. The analysis was carried out with STATA statistical software [20].

\section{Results}

\subsection{Results of the literature search}

The literature search was carried out in April 2015. Its results and the stepwise exclusion process for meta-analysis is described in Fig. 1. A total of 53 publications were retrieved and screened; 37 were not relevant to our analysis and were discarded, as described in the flow chart. Sixteen full-text articles were assessed for eligibility and five of them were excluded because of insufficient data reporting [21,22], lack of a control group [23] or due to concurrent exposure to other known genotoxic compounds $[24,25]$. As a consequence eleven articles [26-36] were left for the inclusion in the review.

\subsection{Description of the studies}

The characteristics of the selected studies are reported in Table 1 . A total of 971 subjects, 479 styrene-exposed workers and 492 controls were included in the analysis. Of the eleven studies selected, four included less than 20 subjects per study group $[26,27]$ or in one of the groups $[28,29]$.

Two studies [26,34] were stratified according to authors' criteria of "low" or "high" level of exposure to styrene measured in workplace-air [26,34] and body fluids [26]. Tomanin et al. [26] comprised workers from two separate factories with higher and 


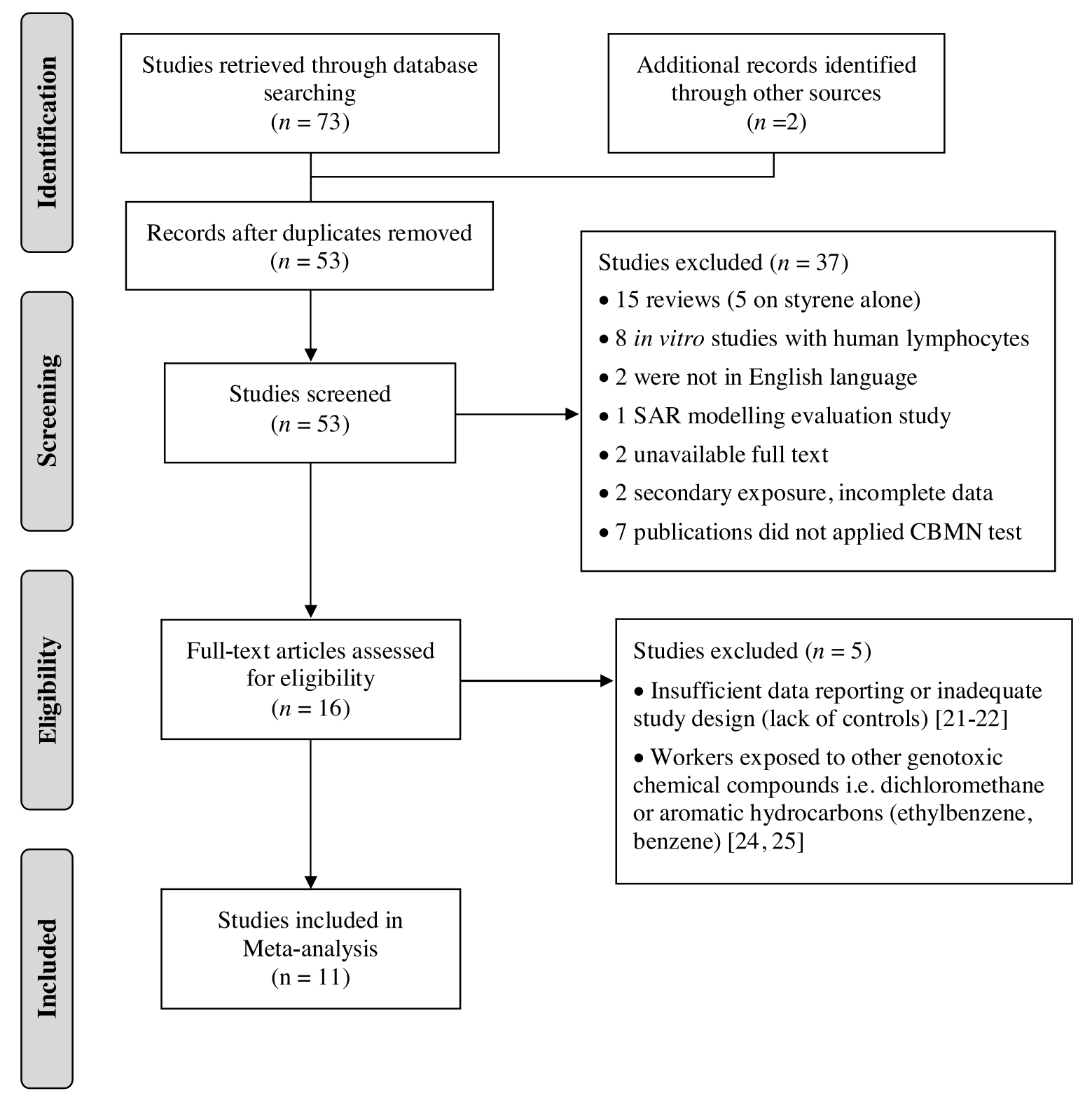

Fig. 1. Flow chart: selection of the literature.

lower levels of exposure to styrene, both groups were matched with separate control groups. Hanova et al. [34] stratified the exposed group into two subgroups of "low exposed" and "high exposed". Thus in total the eleven studies encompassed thirteen groups of workers exposed to styrene. For the current review and meta-analysis suffixes $I$ and $I I$ were assigned to references [26] and [34] whenever necessary to distinguish between "low" (I) and "high" (II) exposed groups.

All studies but one matched control groups on two or more of the following variables: age, gender, or smoking habits. Vodicka et al. [29] was the exception, but according to authors unbalances between exposed and unexposed were controlled for in the statistical analysis. Nevertheless, considering this intrinsic limitation, only the data of one subgroup of workers (Plant A) with similar socio-demographic characteristics of control group (Plant controls) was included in the meta-analysis. A discrepancy in the contribution of males and females was found in Tomanin et al. [26I] and Hannova et al. [34I], with exposed group composed only by males while controls had both genders. This difference was only significant for Hannova et al., probably due to the limited sample size of Tomanin et al. study.

Subjects were interviewed for personal, occupational (previous exposure to styrene or/and any other known genotoxic compounds) and medical history in eight studies [26-28,31-33,35,36]. Co-exposures to other compounds were assessed in three studies for acetone, toluene, lead and chromium [30,31,35]. The usage of personal protective equipment (PPE) during working hours was enquired in three studies $[32,35,36]$; just one reported the use of PPE (gloves and masks) by styrene-exposed workers [32]. The level of exposure to styrene was determined by air monitoring $[29,31,32,34-36]$ and/or measurement of styrene or its metabolites in urine [26-33,35,36] and/or blood [29,34], all studies included a biomarker of internal dose. Mean levels of airborne-styrene exposure ranged between studies from 1.2 to $33 \mathrm{ppm}$. The urinary excretion of MA and PGA (sum of the main styrene metabolites) was analysed in six studies [29,31-33,35,36], in five the reference value of $400 \mathrm{mg} / \mathrm{g}$ creatinine [37] was exceeded [29,31,33,35,36]. Earlier studies only measured the concentration of MA in urine 
Characteristics of the 11 studies included in the meta-analysis on CBMN and human exposure to styrene (alphabetical order).

\begin{tabular}{|c|c|c|c|c|c|c|c|c|}
\hline $\begin{array}{l}\text { Study } \\
\text { (author, occupational } \\
\text { setting, country) }\end{array}$ & Study population & $\begin{array}{l}\text { Styrene Exposure } \\
\text { Mean } \pm \text { SD }\end{array}$ & $\begin{array}{l}\text { Duration } \\
\text { of exposure } \\
\text { Mean } \pm \text { SD } \\
\text { (range) }\end{array}$ & CBMN assay $^{1}$ & QS & \multicolumn{2}{|c|}{$\begin{array}{l}\text { Results and comments } \\
\text { (exposed vs controls) }\end{array}$} & Ref \\
\hline $\begin{array}{l}\text { Anwar and Shamy (1995) } \\
\text { Reinforced plastics } \\
\text { plant, Egypt }\end{array}$ & $\begin{array}{l}\text { Exposed }(\mathrm{n}=70) \\
\text { gender: only males } \\
\text { smoking: } 35 \mathrm{sk}+35 \mathrm{nsk} \\
\text { age: } 40 \pm 7 \\
\text { Controls }(\mathrm{n}=68) \\
\text { gender: only males } \\
\text { smoking: } 35 \mathrm{sk}+33 \mathrm{nsk} \\
\text { age: } 41 \pm 7\end{array}$ & $\begin{array}{l}\text { Dose biomarkers: } \\
\text { Urinary MA (end shift) } \\
103 \pm 96 \mathrm{mg} / \mathrm{g} \text { creat. }\end{array}$ & $15.1 \pm 6.2$ years & $\begin{array}{l}\text { Lymphocyte culture } \\
\text { CytB-3 } \mu \mathrm{g} / \mathrm{mL} \\
\text { Slides stained with Giemsa } \\
\text { Visual scoring: } \\
\text { 500-1000 BNCs/slide }\end{array}$ & 17 & $\begin{array}{l}\text { L-MNed }(\%) \\
\text { L-CA (\%total) } \\
\text { L-CA (\%total with } \\
\text { gaps) } \\
\text { L-MNed were corre } \\
\text { not correlate with } \\
\text { dose }\end{array}$ & $\begin{array}{l}\leftrightarrow(1.09) 6.55 \text { vs } \\
6.00 \\
\uparrow(2.78) 4.00 \text { vs } 1.44 \\
\uparrow(1.76) 6.06 \text { vs } 3.44 \\
\text { ted with CAs but did } \\
\text { ge or biomarkers of }\end{array}$ & [27] \\
\hline $\begin{array}{l}\text { Costa et al. (2012) } \\
\text { Fiberglass reinforced } \\
\text { plastics, Portugal }\end{array}$ & $\begin{array}{l}\text { Exposed }(\mathrm{n}=75) \\
\text { gender: } 54 \mathrm{~m}+21 \mathrm{f} \\
\text { smoking: } 23 \mathrm{sk}+52 \mathrm{nsk} \\
\text { age: } 34 \pm 12 \\
\text { Controls }(\mathrm{n}=77) \\
\text { gender: } 53 \mathrm{~m}+24 \mathrm{f} \\
\text { smoking: } 23 \mathrm{sk}+54 \mathrm{nsk} \\
\text { age: } 37 \pm 11\end{array}$ & $\begin{array}{l}\text { Air (TWA): } \\
30.4 \pm 3.7 \text { ppm } \\
\text { Dose biomarkers: } \\
\text { Urinary MA+ PGA (next morning) } \\
443 \pm 44 \mathrm{mg} / \mathrm{g} \text { creat. }\end{array}$ & $9.0 \pm 10.0$ years & $\begin{array}{l}\text { Whole blood culture } \\
\text { CytB- } 6 \mu \mathrm{g} / \mathrm{mL} \\
\text { Slides stained with Giemsa } \\
\text { Visual scoring: } \\
1000 \text { BNCs/slide }\end{array}$ & 22 & $\begin{array}{l}\text { L-MNed (\%) } \\
\text { L-MNi (\%) } \\
\text { L-SCE } \\
\text { L-TL } \\
\text { Workers with EPHX } \\
\text { genotype had signi } \\
\text { frequency of SCE cc } \\
\text { with EPHX1 "low n } \\
\text { No influence was f } \\
\text { GSTT1, GSTP1 and C } \\
\text { studied }\end{array}$ & $\begin{array}{l}\leftrightarrow(1.15) 2.56 \text { vs } \\
2.22 \\
\leftrightarrow(1.16) 2.63 \text { vs } \\
2.26 \\
\uparrow(1.28) 5.50 \text { vs } 4.31 \\
\leftrightarrow(1.04) 49.39 \text { vs } \\
47.43 \\
\text { \# "high mEH activity" } \\
\text { cantly higher } \\
\text { npared to workers } \\
\text { EH activity" genotype } \\
\text { Ind regarding GSTM1, } \\
\text { 2E1 on the endpoints }\end{array}$ & [36] \\
\hline $\begin{array}{l}\text { Godderis et al. (2004) } \\
\text { Fiberglass- reinforced } \\
\text { plastic factory, Belgium }\end{array}$ & $\begin{array}{l}\text { Exposed }(n=44) \\
\text { gender: only males } \\
\text { smoking: } 23 \text { sk }+21 \mathrm{nsk} \\
\text { age: } 42 \pm 10 \\
\text { Controls }(\mathrm{n}=44) \\
\text { gender: only males } \\
\text { smoking: } 23 \text { sk }+21 \mathrm{nsk} \\
\text { age: } 41 \pm 9\end{array}$ & $\begin{array}{l}\text { Dose biomarkers: } \\
\text { Urinary MA (end shift) } \\
202 \pm 148 \mathrm{mg} / \mathrm{g} \text { creat. }\end{array}$ & $14.2 \pm 10.3$ years & $\begin{array}{l}\text { Whole blood culture } \\
\text { CytB-6 } \mu \mathrm{g} / \mathrm{mL} \\
\text { Slides stained with } \\
\text { Giemsa Visual scoring: } \\
1000 \text { BNCs/slide }\end{array}$ & 21 & $\begin{array}{l}\text { L-MNed (\%) } \\
\text { N-MN (\%) } \\
\text { L-TD (\%) } \\
\text { Significant positive } \\
\text { MNed (\%) and dura } \\
(\%) \text { and styrene exp } \\
\text { positive influence o } \\
\text { MNed frequency (a } \\
\text { Potential co-exposu } \\
\text { levels of lead in blo } \\
\text { urine were below } \mathrm{r}\end{array}$ & $\begin{array}{l}\uparrow(1.48) 3.93 \text { vs } 2.65 \\
\uparrow(2.26) 0.52 \text { vs } 0.23 \\
\leftrightarrow(1) 0.80 \text { vs } 0.80 \\
\text { orrelation between L- } \\
\text { on of exposure; N-MN } \\
\text { sure. Significant } \\
\text { XRCC1 (399) on L- } \\
\text { population) } \\
\text { es analysed, both } \\
\text { d and chromiun in } \\
\text { erence values. }\end{array}$ & [30] \\
\hline $\begin{array}{l}\text { Hanova et al. (2010) } \\
\text { Hand lamination, } \\
\text { Czech Republic }\end{array}$ & $\begin{array}{l}\text { "High" styrene exposure, }>12 \mathrm{ppm} \\
\text { [34II] } \\
\text { Exposed }(\mathrm{n}=43) \\
\text { gender: } 26 \mathrm{~m}+17 \mathrm{f} \\
\text { smoking: } 23 \mathrm{sk}+20 \mathrm{nsk} \\
\text { age: } 37 \pm 11\end{array}$ & $\begin{array}{l}\text { Air: } \\
32.7 \pm 9.4 \mathrm{ppm} \\
\text { Dose biomarkers: } \\
\text { Styrene level in blood }(\mathrm{mg} / \mathrm{L}): \\
1.71 \pm 0.94\end{array}$ & $4.0 \pm 3.6$ years & $\begin{array}{l}\text { Lymphocyte culture } \\
\text { CytB-6 } \mu \mathrm{g} / \mathrm{mL} \\
\text { Slides stained with } \\
\text { Giemsa Visual scoring: } \\
2000 \text { BNCs/slide }\end{array}$ & 17 & $\begin{array}{l}\text { "High" styrene expo } \\
\text { L-MNed (\%o) } \\
\text { SSB in DNA (SSB/ } \\
\left.10^{9} \mathrm{Da}\right)\end{array}$ & $\begin{array}{l}\text { lre, }>12 \mathrm{ppm}[34 \mathrm{II}]: \\
\qquad(1.06) 7.3 \text { vs } 6.8 \\
\qquad(0.43) 0.51 \text { vs } 1.20\end{array}$ & [34] \\
\hline & $\begin{array}{l}\text { "Low" styrene exposure, }<12 \mathrm{ppm} \\
\text { [34I] } \\
\text { Exposed }(\mathrm{n}=28) \\
\text { gender: only male } \\
\text { smoking: } 14 \mathrm{sk}+14 \mathrm{nsk} \\
\text { age: } 41 \pm 12 \\
\text { Controls }(\mathrm{n}=51) \\
\text { gender: } 41 \mathrm{~m}+10 \mathrm{f} \\
\text { smoking: } 35 \mathrm{sk}+16 \mathrm{nsk} \\
\text { age: } 40 \pm 12\end{array}$ & $\begin{array}{l}\text { Air: } \\
1.2 \pm 1.4 \mathrm{ppm} \\
\text { Dose biomarkers: } \\
\text { Styrene level in blood }(\mathrm{mg} / \mathrm{L}) \text { : } \\
0.41 \pm 0.45 \\
\text { Dose biomarkers: } \\
\text { Styrene level in blood }(\mathrm{mg} / \mathrm{L}) \text { : } \\
0.27 \pm 0.25\end{array}$ & $6.9 \pm 4.0$ years & & 17 & $\begin{array}{l}\text { "Low" styrene expos } \\
\text { L-MNed (\%o) } \\
\text { SSB in DNA (SSB/ } \\
\left.10^{9} \mathrm{Da}\right) \\
\text { All population: } \\
\text { mRNA expression 1 } \\
\text { and XPC were nega } \\
\text { styrene concentrati } \\
\text { positively with SSB }\end{array}$ & $\begin{array}{l}\text { re, }<12 \mathrm{ppm} \text { [34I]: } \\
\leftrightarrow(1.06) 7.2 \text { vs } 6.8 \\
\downarrow(0.64) 0.77 \text { vs } 1.20 \\
\\
\text { vels of XRCC1, hOGG1 } \\
\text { vely correlated with } \\
\mathrm{n} \text { in air and blood and }\end{array}$ & \\
\hline $\begin{array}{l}\text { Laffon et al. (2002) } \\
\text { Fiberglass-reinforced-plastics } \\
\text { factory, Spain }\end{array}$ & $\begin{array}{l}\text { Exposed }(n=14) \\
\text { gender: only males } \\
\text { smoking: } 5 \text { sk }+9 \mathrm{nsk} \\
\text { age: } 44 \pm 9\end{array}$ & $\begin{array}{l}\text { Dose biomarkers: } \\
\text { Urinary MA (end shift) } \\
3 \text { samplings } \\
313 \pm 91 \mathrm{mg} / \mathrm{g} \text { creat. }\end{array}$ & $17.0 \pm 6.0$ years & $\begin{array}{l}\text { Whole blood culture } \\
\text { CytB-6 } \mu \mathrm{g} / \mathrm{mL} \\
\text { Slides stained with DAPI }\end{array}$ & 16 & $\begin{array}{l}\text { L-MNed }(\%) \\
\text { L-MNi }(\%)\end{array}$ & $\begin{array}{l}\uparrow(1.81) 21.57 \text { vs } \\
11.90 \\
\uparrow(1.77) 24.63 \text { vs } \\
13.91\end{array}$ & [28] \\
\hline
\end{tabular}


Controls $(n=30)$

gender: only males

smoking: $16 \mathrm{sk}+14 \mathrm{~ns}$

age: $38 \pm 8$ years

Migliore et al. (2006)
Fiberglass reinforced-plastics
factories, Italy
Migliore et al. (2006)
Fiberglass reinforced plastics
and polyester resin industries,
Italy

gender: only males

smoking: no information

age: $32 \pm 5$

Controls $(n=25)$

gender: only males

smoking: no

age: $32 \pm 7$

Exposed $(n=95)$
gender: $76 m+19 f$

and polyester resin industries, smoking: $51 \mathrm{sk}+44 \mathrm{nsk}$

age: $35 \pm 8$

Controls $(n=98)$

gender: $67 \mathrm{~m}+31 \mathrm{f}$

smoking: $41 \mathrm{sk}+57 \mathrm{nsk}$

age: $37 \pm 9$

Teixeira et al (2004)

Teixeira et al. (2010) plastics, Portugal
$325 \pm 71 \mathrm{mg} / \mathrm{g}$ creat.

Dose biomarkers:

Urinary MA + PGA (end shift)

$630 \pm 4 \mathrm{mg} / \mathrm{g}$ creat

\section{Air:}

$8.7 \pm 0.9 \mathrm{ppm}^{*}$

Dose biomarkers:

Urinary MA+PGA (end shift)

$300 \pm 338 \mathrm{mg} / \mathrm{g}$ creat

\section{$11.5 \pm 8.1$ years Whole blood culture \\ CytB-6 $\mu \mathrm{g} / \mathrm{mL}$ \\ Slides stained with Giems \\ Visual scoring: \\ $2000 \mathrm{BNCs} /$ slide \\ For FISH analysis slides were stained with DAPI}

Exposed $(n=28)$

gender: $18 \mathrm{~m}+10 \mathrm{f}$

smoking: 8 sk+20nsk

age: $35 \pm 8$

Controls $(n=28)$

gender: $18 \mathrm{~m}+10 \mathrm{f}$

smoking: 9sk+19nsk

age: $36 \pm 10$

\section{Air (TWA):}

$27.0 \pm 5.0 \mathrm{ppm}(\mathrm{TWA})$

Dose biomarkers:

Urinary MA+ PGA (next morning)

$401 \pm 73 \mathrm{mg} / \mathrm{g}$ creat.
$12.0 \pm 10.0$ years Whole blood culture CytB-6 $\mu \mathrm{g} / \mathrm{mL}$ Slides stained with Giems Visual scoring: 1000 BNCs/slide

Exposed $(\mathrm{n}=52)$ gender: $34 m+18 f$ smoking: only nsk age: $34 \pm 12$

Controls $(\mathrm{n}=54)$ gender: $36 \mathrm{~m}+18 \mathrm{f}$ smoking: only nsk age: $37 \pm 11$

\section{Air (TWA):}

(TWA)

Dose biomarkers:

$419 \pm 52$ mg

$10.0 \pm 10.0$ years Whole blood culture

CytB- $6 \mu \mathrm{g} / \mathrm{mL}$

Slides stained with Giemsa

Visual scoring:

$000 \mathrm{BNCs} /$ slide

L-SCE/cell

$\uparrow(1.38) 3.51$ vs 2.55

$\mathrm{L}-\mathrm{TL}(\mu \mathrm{m})$

$\uparrow(1.12)$
43.34 4.68 vs

Significant association between L-MNed (\%) with duration of exposure (also found for L-SCE and L-TL)

Among exposed workers no influence on the effect biomarkers was observed of GSTM1 and GSTT1 genotypes

$18 \quad$ L-MNed (\%) $\quad \uparrow(2.22) 13.8 \mathrm{vs} 6.2$

C+MNBN $\quad \uparrow(2.20) 7.34$ vs 3.34 $\begin{array}{ll}\text { C-MNBN } & \uparrow(2.22) 6.09 \text { vs } 2.21\end{array}$

\% TDNA (sperm $\quad \uparrow(1.49) 11.02$ vs 7.42

(ells)

$\uparrow(1.49) 11.02$ vs 7.42

$\begin{array}{ll}\text { L-MNed (\%) } & \uparrow(1.50) 13.8 \text { vs } 9.2 \\ \text { C+MNBN } & \uparrow(1.56) 7.43 \text { vs } 4.75 \\ \text { C-MNBN } & \uparrow(1.80) 5.76 \text { vs } 3.20 \\ \text { L-CA (\%total) } & \leftrightarrow(0.96) 2.4 \text { vs } 2.5 \\ \text { L-CA (\%total with } & \leftrightarrow(1.06) 3.8 \text { vs } 3.6\end{array}$

gaps)

$C+$ MNBN were significantly correlated with MA+ PGA

L-MNed (\%) and C+MNBN were

significantly

correlated with minor styrene metabolites in urine (4-VPT)

Among exposed we

Anong exposed workers GSTT1 null

individuals showed a significant higher frequency of MNed compared to GSTT1 positive subjects.

No significant influence was found

regarding EPHX1, GSTM1, GSTP1 and NAT2

on cytogenetic biomarkers studied.

$\begin{array}{ll} & \leftrightarrow(1.30) 3.63 \mathrm{vs} \\ \text { L-MNi (\%) } & 2.78 \\ \leftrightarrow(1.30) 3.68 \mathrm{vs}\end{array}$

L-MNi (\%) $\quad \leftrightarrow$

2.82

L-SCE/cell $\quad \uparrow(1.40) 7.18 v s 6.30$

styrene exposure have significantly higher levels of urinary MA + PGA

Potential co-exposures analysed: toluene and acetone were present, air levels were less than $1 \%$ of the styrene concentration

22

L-MNed (\%o) $\leftrightarrow(1.08) 2.44$ vs 2.26

L-MNi (\%) $\quad \leftrightarrow(1.08) 2.50$ vs

$\uparrow(1.23) 5.34$ vs 4.15 $\leftrightarrow(1.03) 49.20 \mathrm{vs}$ 47.6

L-MNi were significantly correlated with L-SCE

Potential co-exposures analysed: toluene and acetone were present, air levels were $<1 \%$ of the styrene concentration

17 "Higher" level of styrene exposure [26II] 
Table 1 (Continued)

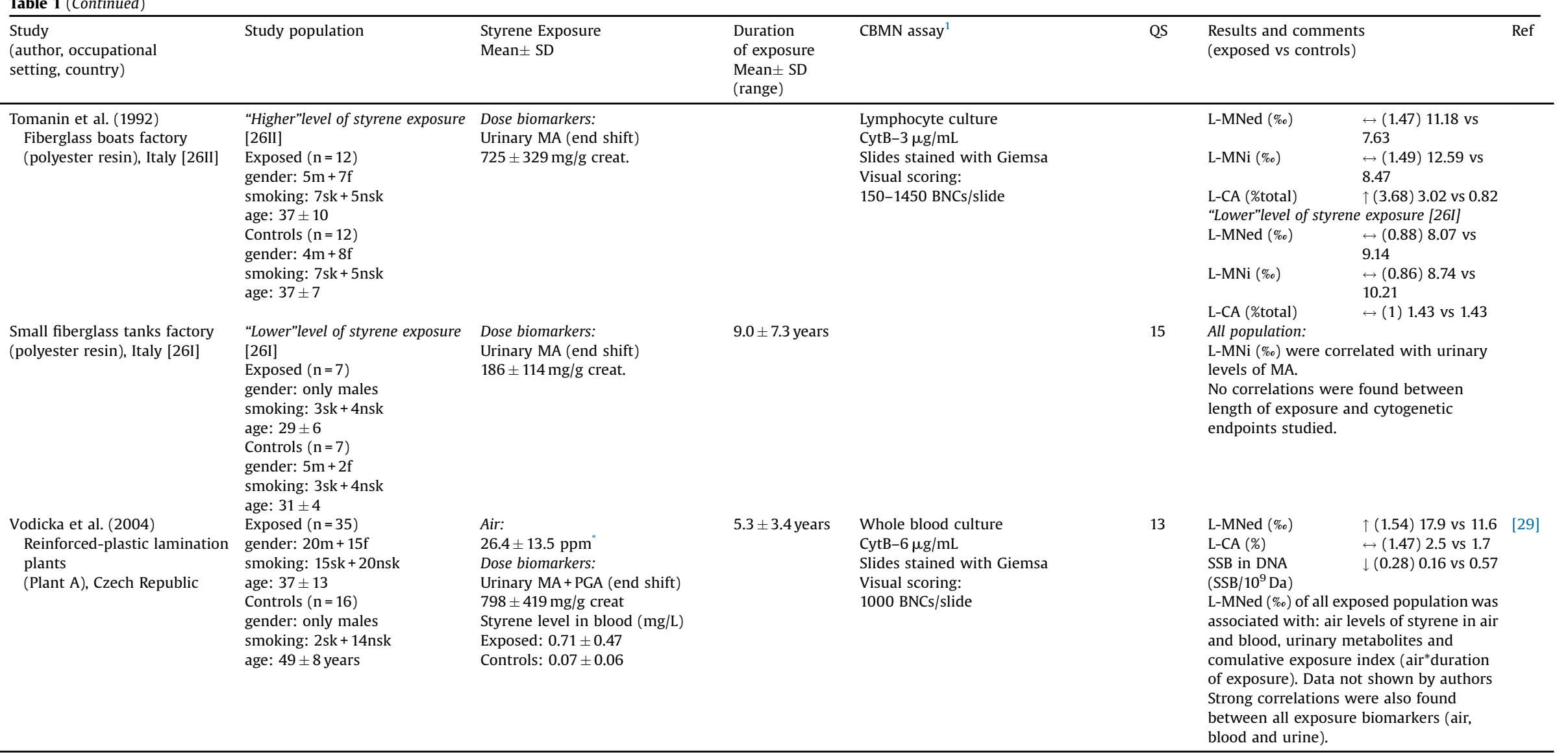

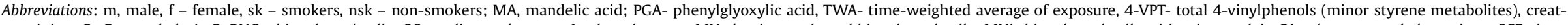

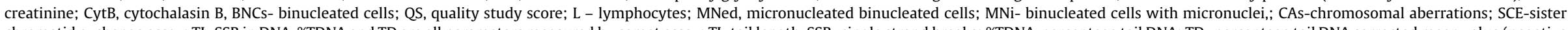

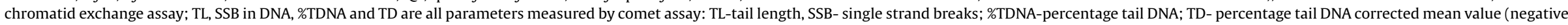

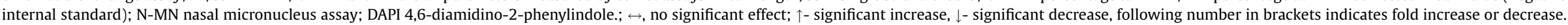

${ }_{1}^{1}$ L-CBMN assay protocol: culture, stain used and number of binucleated cells (BNCs) scored.

\# mEH enzymatic activity (expected), classification of EPHX1 genotypes according to Sarmanova et al. [69].

values converted from $\mathrm{mg} / \mathrm{m}^{3}$ to $\mathrm{ppm}$ ( $1 \mathrm{ppm}$ airborne styrene $=4.26 \mathrm{mg} / \mathrm{m}^{3}$ airborne styrene) 
[26-28,30] the levels found were below the limit value of $800 \mathrm{mg} / \mathrm{g}$ recommended by $\mathrm{ACGIH}^{\circledR}$ [38]. Styrene concentration in venous blood was assessed by Vodicka et al. [29] and Hannova et al. [34], in both studies the biological exposure indice (BEI) of $0.2 \mathrm{mg} / \mathrm{L}$ was exceeded. Overall in six of the eleven studies (seven of the thirteen exposed groups) workers presented levels of exposure to styrene above international reference values.

\subsubsection{CBMN assay}

Micronucleus frequency was increased in twelve of the thirteen styrene-exposed groups, but only five reached significance [28,29,31-33].

Tomanin et al. [26] found a non-significant decrease on micronucleus frequency in group I "lower" level of exposure however, it should be noted the limited number of individuals analysed (there was an outlier in the control group). When the two groups of workers were considered together micronucleus frequency was increased in workers compared to controls, but not significantly.

Most studies evaluated the effects of potential confounders such as smoking, age, and gender on micronuclei frequencies. Two studies $[30,28]$ reported a significant increase of micronucleus frequency in smokers. Migliore et al. [32] found a significant decrease in centromere-negative micronuclei (MN-FISH assay) among smokers, but total micronuclei were not affected by this confounder. Anwar and Shamy [27] and Teixeira et al. [35] enrolled only non-smokers. Age significantly influenced micronuclei frequency in six studies [29,30,32,34-36], but in three [26-28] no significant association was found; no data was reported in the other studies [31,33]. Concerning gender, five studies reported a significant increase of micronucleus frequency in females compared to males [29,31,34-36], although in Migliore et al. [32] the difference disappeared when corrected for age. Tomanin et al. [26] did not assess the influence of gender on the endpoints studied. The four studies remaining only enrolled male subjects $[27,28,30,33]$.

Concerning dose/exposure-response relationships, five studies reported a significant positive association between micronuclei frequency and styrene exposure measured in air [29], internal dose biomarker [26,29,32] or duration/years of exposure [28-30]. For the remaining studies no significant association was found either for micronuclei or other effect biomarker, with the exception of Teixeira et al. [35] for sister-chromatid exchange frequency (correlation with air and urine levels).

\subsubsection{CBMN assay vs other biomarkers}

Other genotoxicity biomarkers besides micronuclei were analysed in peripheral blood lymphocytes of styrene exposed workers, namely chromosomal aberrations (CAs), sister-chromatid exchange (SCE) and comet assay (DNA damage assessed by different parameters). Most studies have evaluated one $[26,27,30-34]$ or two $[28,29,35,36]$ of the above endpoints, however due to numerical and practical reasons (e.g. different assays used among studies) no statistical evaluation of the agreement between assays and CBMN was possible. A descriptive comparison of results from the lymphocyte CBMN assay and other DNA damage biomarkers is shown in Fig. 2. With the exception of Hanova et al. [34] all studies reported significant positive increases in one of the genotoxicity biomarkers evaluated. CAs frequencies were assessed in four studies [26,27,29,32] with two studies reporting significant increases in workers compared to referents [26,27]. Anwar and Shamy [27] reported a positive association between micronuclei and CA, whereas no association was found in Vodicka et al. [29] study. All studies measuring SCE reported significantly higher frequencies in workers compared to controls $[28,31,35,36]$. A total of seven studies reported data on DNA damage evaluated by comet assay [28-30,34-36] with positive and negative outcomes. None of the studies reported association between micronuclei and SCE frequencies, nor with the comet assay parameters. Besides peripheral blood lymphocytes other tissues/cells were analysed to assess styrene genotoxicity, namely, nasal epithelial cells tested for micronuclei formation [30] and sperm cells assessed for DNA damage by the comet assay [33]. In the first study, micronucleated nasal cells were significantly higher in workers compared to referents. Moreover a positive correlation with average styrene exposure was observed, but no association between micronuclei formation in nasal cells and lymphocytes was detected. Migliore et al. [33] found a positive correlation

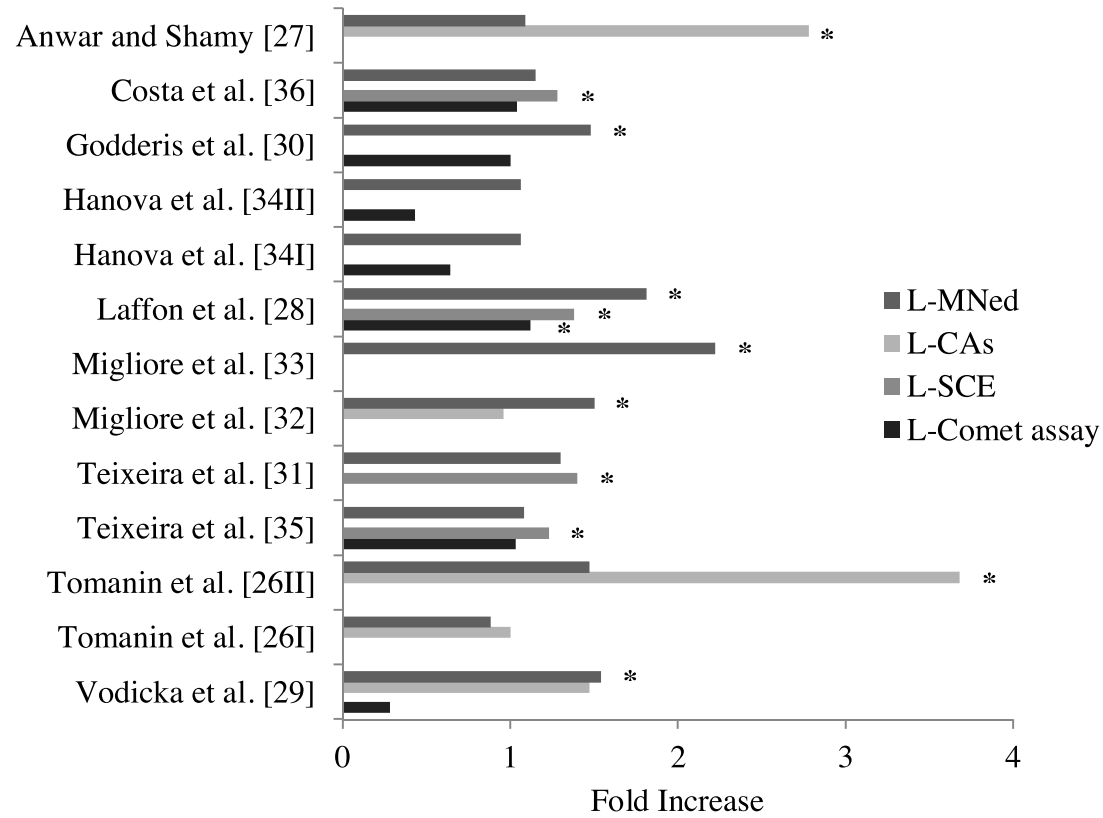

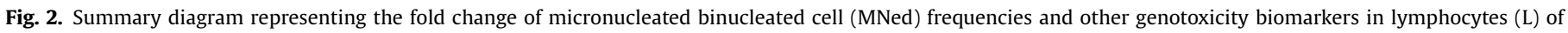
styrene exposed workers compared to referents (CAs-chromosomal aberrations; SCE-sister chromatid exchange assay; ${ }^{*} P<0.05$, significant difference reported). 
between the frequency of micronuclei in peripheral lymphocytes and DNA damage in sperm cells, even when adjusted for age.

\subsection{Laboratory methods}

All studies selected for the meta-analysis applied the CBMN assay. Cell cultures were prepared from whole blood [28, $30-33,35,36]$ or from lymphocytes isolated from whole blood samples $[26,27,29,34]$. Cytochalasin B (CytB) was added at a final concentration of $6 \mu \mathrm{g} / \mathrm{mL}$ after $44 \mathrm{~h}$ incubation in nine studies [2836]; Tomanin et al., [26] and Anwar and Shamy [27] added $3 \mu \mathrm{g} / \mathrm{mL}$ CytB after $32 \mathrm{~h}$ of cells incubation. The stain used in most studies was Giemsa, with the exception of Laffon et al. [28] that used 4,6diamidino-2-phenylindole (DAPI). Different references were given regarding scoring criteria [39-46]. All but two studies [26,27] scored a minimum of a thousand binucleated lymphocytes per subject.

\subsection{Meta-analysis}

After applying inclusion criteria eleven studies, further broken down in thirteen groups, evaluating the frequency of micronucleated cells (MNed) in subjects exposed to styrene were included in the meta-analysis. Six of them evaluated also micronuclei frequency $(\mathrm{MNi})$. A forest plot reporting for each study mean ratio (MR) estimate and relative $95 \%$ confidence intervals $(95 \% \mathrm{CI})$ is shown in Fig. 3. All studies but Tomanin et al. [26I] showed an increased frequency of MNed in exposed subjects, ranging from a MR of $1.06(0.85 ; 1.31)$ to a maximum of $2.23(1.58 ; 3.13)$, six of them reaching statistical significance. The high heterogeneity between studies $\left(\mathrm{I}^{2}=67 \% ; \mathrm{P}<0.001\right)$ recommended the use of random effects model to estimate a meta-MR of 1.34 (1.18; 1.52 ; $\mathrm{P}<0.001)$. The same analysis was applied to those studies evaluating $\mathrm{MNi}$, and parallel results were found with an overall estimate of 1.29 ( $1.04 ; 1.60)$. To take into account the influence of single studies on meta-estimates of effect, the funnel plot and the Egger test, were evaluated together with sensitivity analysis. The funnel plot for the thirteen study groups on MNed can be observed in Fig. 4. The triangular distribution of studies included in the meta-analysis shows the expected inverse relationship between the effect estimates from individual studies against the standard error of the effect. The shape of the figure and the inclusion of most studies within the triangle stand for a low probability of publication bias. The lack of asymmetry in the funnel plot was confirmed by the Egger test $(P=0.253)$. Sensitivity analysis was performed removing all studies one by one and rerunning the analysis. The results of all estimates of the meta-MR ranged from 1.30 to 1.37. Results for the MNi were similar and were not reported here. The meta-regression analysis which reported the adjusted estimate of the styrene effect taking into account possible confounding variables such as gender, age and smoking habits is reported in Table 2 . Interestingly the heterogeneity in this model dropped to non-significant values, confirming the validity of the analysis. Also this model estimated an effect of exposure in the range of $30 \%$ confirming the reliability of the meta-analysis (metaMR 1.39; 95\% CI 1.28-1.51). No association was found with selected dose biomarker (urinary MA+ PGA) nor with duration of exposure in six studies.

The inclusion of quality score (QS) into the meta-analysis did not substantially modified the results presented above. In Fig. 5 the study groups were stratified by tertiles of QS and a meta-MR was estimated for each tertile. The results ranged from 1.43 , to 1.30 , to 1.34 without any evident trends by study quality. When also the term for quality was included in the meta-regression model for the MNed, the meta-MR for styrene exposure increased to 1.48 , although the term did not significantly contributed to the model $(\mathrm{MR}=1.00, \mathrm{P}=0.842)$.

\section{Discussion}

Previous reviews were inconclusive with regard to micronucleus assay sensitivity to evaluate genomic instability and/or DNA damage in human lymphocytes induced by styrene occupational exposure. Across the studies appraised different methodologies

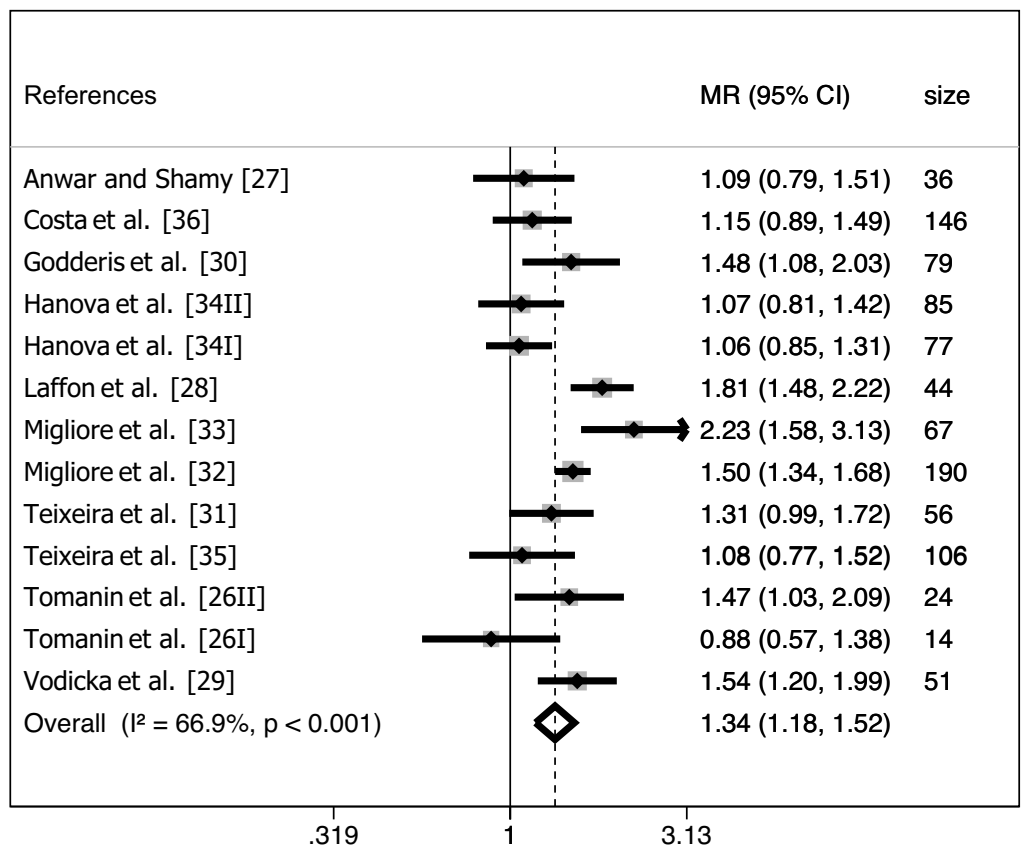

Fig. 3. Forest plot of the effect of styrene exposure on micronuclei frequencies in the selected studies, with estimates of mean ratios (MR). 


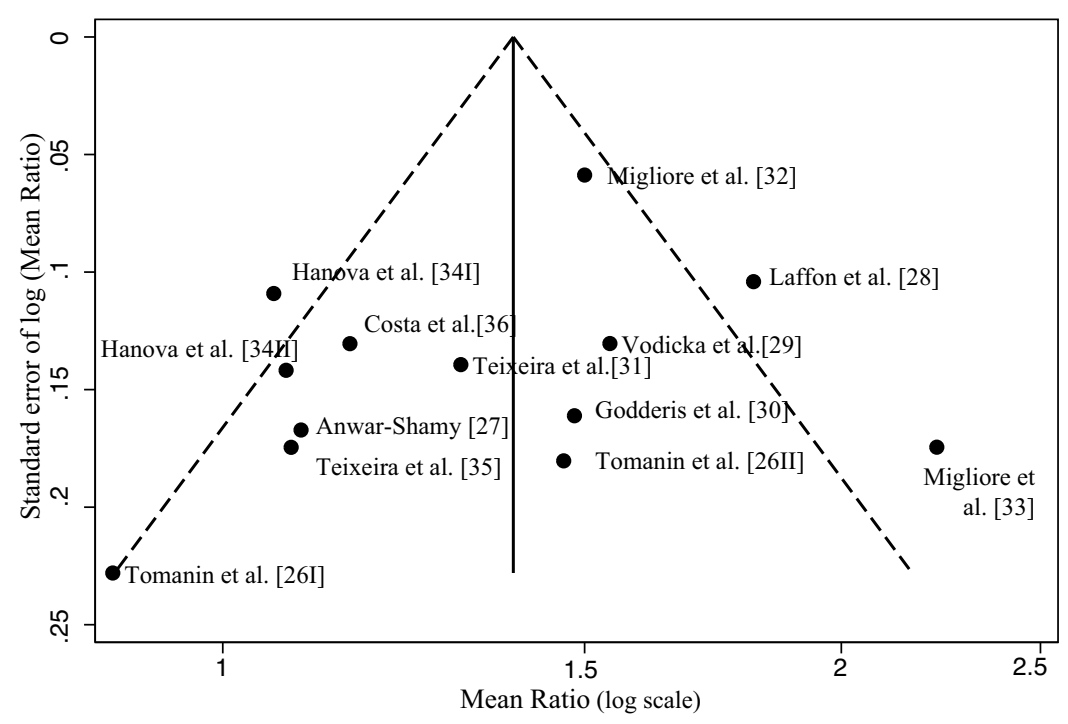

Fig. 4. Funnel plot with studies distribution within pseudo $95 \%$ confidence limits.

Table 2

Random effect modelling of meta-regression estimates.

\begin{tabular}{|c|c|c|c|}
\hline Variable & Mean Ratio & 95\% Confidence interval & $P$-value \\
\hline \multicolumn{4}{|l|}{ Pooled random effect } \\
\hline Controls & 1.00 & & \\
\hline Exposed & 1.38 & $1.28-1.50$ & $<0.001$ \\
\hline$\% \Delta$ Males between Exposed and Controls & 0.98 & $0.97-0.99$ & 0.008 \\
\hline$\% \Delta$ smokers between Exposed and Controls & 1.02 & $1.01-1.03$ & 0.009 \\
\hline$\Delta$ mean age between Exposed and Controls & 1.07 & $1.04-1.11$ & 0.001 \\
\hline
\end{tabular}

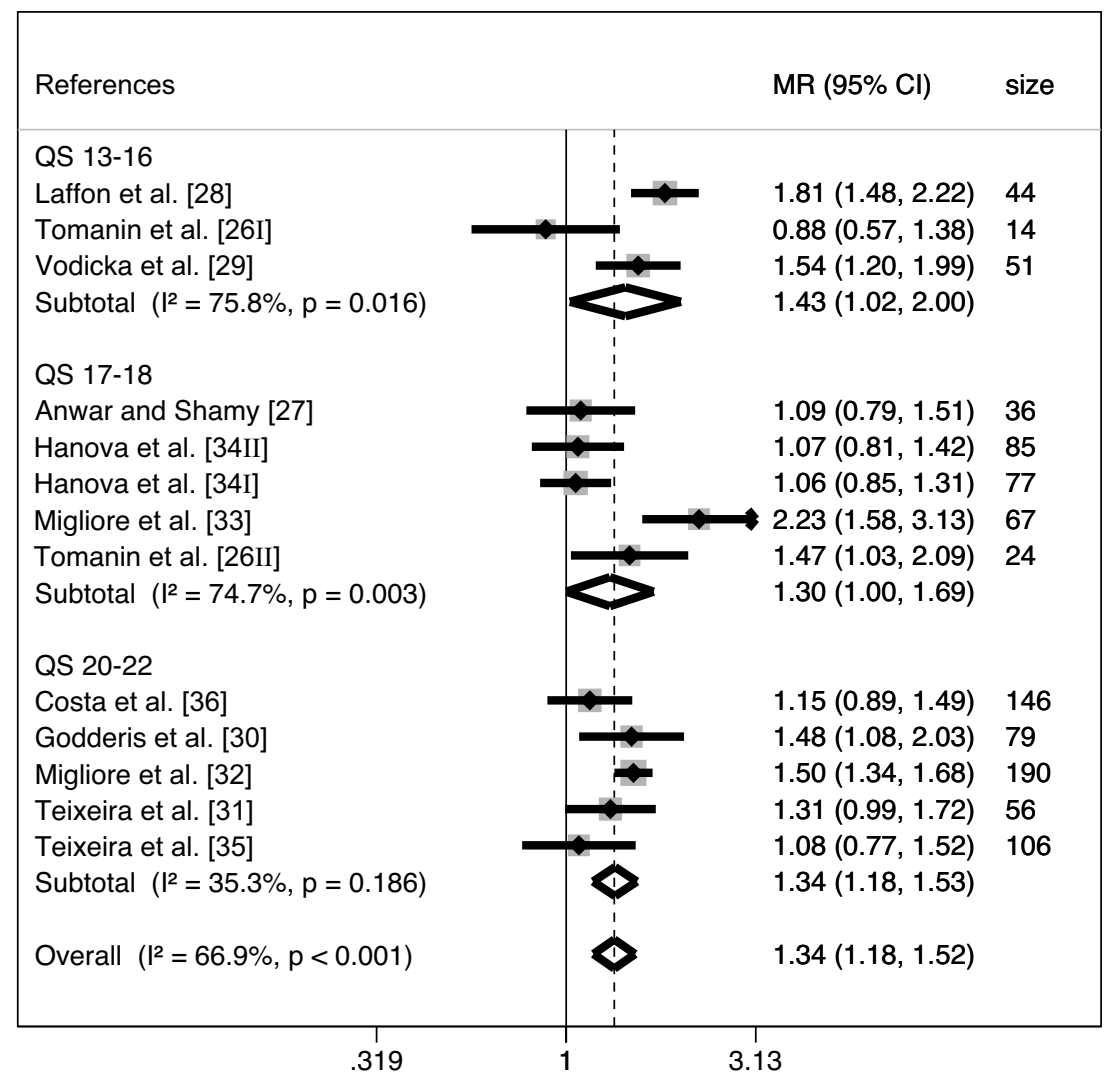

Fig. 5. Forest plot of the influence of quality scores (QS) on results obtained for overall effect of styrene in micronuclei frequencies, with mean ratio (MR) estimates. 
were used to assess micronuclei formation, especially in earlier studies [47-50]. Our systematic review focused on studies using CBMN assay selected eleven studies published between 1992 and 2012 eligible for meta-analysis. The analyses revealed convincing evidence linking exposure to styrene with micronuclei frequency. Consistency among studies was good indicating that subjects exposed to styrene have about 30\% higher level of DNA damage measured by CBMN assay, regardless of gender, age or smoking status. It should be noted that the inclusion of a study-quality score (QS) into the meta-analysis did not substantially modified the estimated effect, meaning that the quality of the studies have no influence in the association found. Hence, these results seems to support the biological relevance of micronuclei testing (as measured by CBMN) to evaluate genomic instability and/or DNA damage in lymphocytes of subjects occupationally exposed to styrene.

The present review has some limitations, the first being the low number of studies available in the literature for inclusion in the meta-analysis which hindered more firm conclusions (e.g for dose biomarker association, influence of confounders). A second aspect found is related to the unbalanced number of females and smokers between exposed and control groups in few studies. This is an important issue since females in general have higher frequencies of micronucleus than man and therefore inclusion of females in group controls [26I, 34I] can potentially create negative bias. Styrene is one of the components of tobacco and tobacco smoke, however studies are conflicting regarding its influence on micronucleus frequency. Nevertheless this mix did not influence meta-estimates but may have contributed to some of the observed inter-study heterogeneity. Thirdly, the risk of partial overlapping of exposed groups between published papers cannot be completely overruled since there is more than one study published by the same research group. However, the presence of different sociodemographic characteristics between studies seems to rule out this inconvenient. Across studies there was insufficient data on the occupational activity of participants used as controls and on other lifestyle variables such as dietary habits and alcohol intake that may influence micronucleus frequency, thus this data was not analysed. Finally, despite some studies have reported dose-effect correlations [28-30,32] no firm conclusions can be drawn on the association between dose biomarkers and micronucleus frequency. On the other hand, the results of this review, which are based on the most recent research in the field, are supported by the use of restrictive criteria to select studies, and a technical homogeneity which add values to the positive results, largely confirmed by individual studies, as evident by forest plots and sensitivity analysis. The independence of risk estimates from confounding factors and study quality further increases the reliability of these results.

One of the main reasons pointed for the inconsistency of results among previous studies was concurrent exposure to other genotoxic substances. Therefore this issue was carefully analysed and studies reporting co-exposure to other known genotoxic chemicals were excluded from our analysis. By coincidence all studies eligible for the analysis took place in reinforced-plastic industries, according to IARC studies comprising glass fibrereinforced plastics workers are more informative because they are exposed to high levels of styrene and have less potential for exposure to other substances [2]. Three studies reporting coexposure to other compounds (acetone, toluene, lead and chromium) were included in the analysis. Acetone and toluene air levels were $<1 \%$ of the styrene concentration [31,35]. As for metals tested because of control group occupation, the levels were under reference limit values [30].

The low number of studies and the different internal dose biomarkers evaluated limit possible conclusions on dose-effect relationships. Biological monitoring of styrene in humans is classically performed in urine or blood; the total concentration of MA and PGA in urine sampled at the end of the work shift is the most used internal-dose biomarker. In the present review the time period between the first study and the last is 20 years. During that time the biological compound of reference changed (MA to MA + PGA) as well as the biologic exposure indices and sampling times (end of shift, prior to next shift). From our Table 1 we can observe that ten of the eleven studies used urine as the biological matrix of choice, six of which measured MA + PGA (earlier studies only assessed MA). Air level of styrene exposure, personal protective devices, workers tasks, type of moulding process and sampling time are factors that may influence MA + PGA levels [51]. For all studies assessing environmental and biological monitoring strong correlations were found between styrene air-levels and MA + PGA levels (other studies did not assessed workplace air). As for sampling time, half of the six studies sampled urine at the end of shift and the other half prior to next shift. Nowadays, the end of the shift is considered to be the best time for sampling urine for MA + PGA analysis for styrene exposure biomonitoring. This may explain why in studies that sampled urine prior to next shift $[31,35,36]$ no correlation was found between MA + PGA levels and micronucleus frequency. On the other hand, MA + PGA levels reflect the exposure at the moment of sampling and so are dependent of workplace conditions (e.g. seasonality on working load) as for micronucleus frequency is an expression of chronic exposure, a measure of cumulative chromosomal damage, thus in such a diverse and short number of studies the lack of association is not surprising. Although no consistent association was found across studies between CBMN assay and dose biomarkers evaluated, it should be noted that styrene-exposed workers showed an increase of micronucleus frequency in all studies analysed. So CBMN was efficient in detecting damage in a variety of exposure levels measured by the different dose biomarkers used in the studies.

Duration of exposure and micronucleus frequency were significantly associated in three studies [28-30], the high dispersion observed in working years and the minimum duration criteria may explain the lack of significant association in some studies.

Some minor differences were identified across studies in technical features of the CBMN assay that may have contributed for the results found in some studies, namely lymphocyte culture (vs whole blood culture) $[26,27,34]$, time of Cyt-B addition and concentration ( $3 \mu \mathrm{g} / \mathrm{mL}$ ) [26,27]. It was observed that erythrocytes are able to oxidize styrene to SO (styrene-genotoxic intermediate) while lymphocytes have the potential to inactivate SO through metabolism by microsomal epoxide hydrolase [52], a balance that may be disrupted in lymphocyte cultures with the inactivation of So leading to different outcomes comparing to whole blood cultures. The optimal Cyt-B concentration for lymphocyte isolated cultures is $4.5 \mu \mathrm{g} / \mathrm{mL}$, at $3 \mu \mathrm{g} / \mathrm{mL}$ Cyt-B was shown to be less effective in blocking cytokinesis [53,54]. Another different aspect identified in [26] and [27] studies critical to CBMN assay is the time of Cyt-B addition. Cyt-B may take up to $6 \mathrm{~h}$ before it starts to exert its cytokinesis-blocking action so ideally it should be added $6 \mathrm{~h}$ before the first mitosis so that all the observed binucleated cells are in fact once-divided cells [54]. For lymphocytes is usually $44 \mathrm{~h}$ after culture, in [26] and [27] it was added after only $32 \mathrm{~h}$. According to Fenech et al. [54] micronuclei tend to get lost in subsequent divisions and the micronuclei frequency in a second division cell is likely to be less than that in a first division cell after a genotoxic insult.

It is generally agreed that styrene exerts toxicity through its metabolic conversion to SO and subsequent induction of DNA damage [55] the metabolic rate of styrene is regulated at the oxidation step by CYP2E1 [56]. DNA adducts induced by styrene 
and SO have been consistently identified in human cells, experimental animals, and occupationally exposed individuals [3,57-59]. In vitro studies with human lymphocytes have demonstrated SO ability to form DNA adducts and to cause single-strand breaks and cytogenetic alterations in a dose-related manner [60,61]. In human biomonitoring studies exposure markers of styrene were found to correlate with lymphocyte cytogenetic alterations and DNA strand-breakage measured by comet assay $[15,28,62]$. Furthermore the majority of studies show significant increases in CAs frequency and to a lesser extent of SCE frequency in styrene-exposed workers compared to referents [2]. The available data on styrene/SO genotoxicity from in vitro and human in vivo studies suggests a clastogenic mode of action as the primary mechanism of CA and micronucleus formation. Moreover, DNA single-strand breaks (SSBs) has been suggested as the principal lesion that leads to SCE formation. The mechanism is likely to involve an unrepaired single-strand break converted to a double-strand break upon replication fork collapse, and homologous recombination repair to facilitate accurate repair of lesion [63].

In our review genetic polymorphism of styrene-metabolizing enzymes such as CYP2E1, microsomal epoxide hydrolase, glutathione-S-transferase (GST) M1, and GSTT1 were found to modulate the levels of urinary metabolite concentrations [31] and cytogenetic endpoints [32,36]. Also in vitro experiments demonstrate that CYP1A1, CYP2E1, EPHX1 and GSTP1 polymorphisms were associated with the levels of genetic lesion induced by styrene and SO in human leukocytes $[64,65]$. This is in agreement with several other studies suggesting that genetic susceptibility may be important in styrene-mediated genotoxicity [66,67]. However, these results must be cautiously interpreted since the size of the study populations limits the power of further conclusions.

Susceptibility is also linked to the individual capacity to repair DNA lesions induced by exposure to genotoxic agents, a deficient repair may lead to genetic instability. Three studies included in the present review have evaluated repair-genetic polymorphisms [30], gene expression levels [34] and DNA repair capacity ( $\gamma$-ray and 8oxoguanine induced lesions) [29,34]. Micronucleus frequency was significantly affected by BER polymorphic gene XRCC1 (399) [30]. Interestingly $m R N A$ expression levels of XRCC1, hOGG1 and XPC were negatively correlated with styrene exposure biomarkers but positively with SSBs measured by comet assay [34], which is in accordance to [30] result and with the proposed styrene genotoxicity mechanism. These results also suggests that BER pathway plays an important role in the repair of styrene-exposure induced DNA lesions. DNA repair capacity, determined by challenge assay measured by comet assay was associated with the duration of exposure to styrene [34] and styrene exposure parameters [29]. Furthermore a study testing the effects of styrene airborne-exposure on DNA damage and DNA repair at levels below reference limit value $(20 \mathrm{ppm})$ found an increased oxidative DNA damage and induction of expression of DNA repair genes, as well as a decreased DNA repair capacity [68]. These results highlight the need for further research with a multiple biomarker approach comprising larger populations and with reliable exposure characterization (including concomitant exposures).

Overall an increase of micronucleus frequency in styreneexposed groups was observed, but only reached significance in five. Analysing the six studies where a non-significant increase was found [26,27,31,34-36] a number of factors mainly related to biological sampling and CBMN methodology may have contributed to the results observed.

In summary, our systematic review and meta-analysis of most recent literature on styrene exposure identified a 34\% overall increase of genomic instability and DNA damage in exposed workers as compared to unexposed controls (as measured by
CBMN assay). The consistency of results in individual studies, the independence of this result from major confounding factors and form the quality of the study strengthens the evidence of risk estimates.

\section{Conflict of interest}

The authors declare that there are no conflicts of interest.

\section{Acknowledgments}

The work of SC and CS was supported by the Portuguese Foundation for Science and Technology (FCT) under the grants SFRH/BPD/100948/2014 and SFRH/BPD/96196/2013. The work of SB was supported by grants funded by the Associazione Italiana per la Ricerca sul Cancro.

\section{References}

[1] J. Rueff, J.P. Teixeira, L.S. Santos, J.F. Gaspar, Genetic effects and biotoxicity monitoring of occupational styrene exposure, Clin. Chim. Acta 399 (1-2) (2009) 8-23.

[2] NTP (National Toxicology Program), Report on Carcinogens, Twelfth EditionStyrene, US Department of Health and Human Services, Public Health Service, National Toxicology Program, Research Triangle Park, NC, 2011 383-391 pp..

[3] International Agency for Research on Cancer (IARC), IARC Monographs on the Evaluation of Carcinogenic Risks to Human, Some Traditional Herbal Medicines, Some Mycotoxins, Naphthalene and Styrene, vol. 82, World Health Organization, Lyon, France, 2002 437-550 pp..

[4] M. Kogevinas, G. Ferro, A. Andersen, T. Bellander, M. Biocca, D. Coggon, V. Gennaro, S. Hutchings, H. Kolstad, I. Lundberg, E. Lynge, T. Partanen, R. Saracci, Cancer mortality in a historical cohort study of workers exposed to styrene. Scand, J. Work Environ. Health 20 (4) (1994) 251-261.

[5] H.A. Kolstad, E. Lynge, O. Olsen, N. Breum, Incidence of lymphohematopoietic malignancies among styrene-exposed workers of the reinforced plastics industry. Scand, J. Work Environ. Health 20 (4) (1994) 272-278.

[6] E. Delzell, N. Sathiakumar, J. Graff, M. Macaluso, G. Maldonado, R. Matthews, An updated study of mortality among North American synthetic rubber industry workers, Res. Rep. Health Eff. Inst. 132 (1-63) (2006) 65-74.

[7] C. Bolognesi, M. Fenech, Micronucleus assay in human cells: lymphocytes and buccal cells, Methods Mol. Biol. 1044 (2013) 191-207.

[8] M. Kirsch-Volders, S. Bonassi, S. Knasmueller, N. Holland, C. Bolognesi, M.F. Fenech, Commentary: critical questions, misconceptions and a road map for improving the use of the lymphocyte cytokinesis-block micronucleus assay for in vivo biomonitoring of human exposure to genotoxic chemicals-a HUMN project perspective, Mutat. Res. Rev. Mutat. Res. 759 (2014) 49-58.

[9] OECD TG 487, OECD guideline for the testing of chemicals, No. 487, In Vitro Mammalian Cell Micronucleus Test (MNvit), Organization for Economic Cooperation and Development, Paris, France, 2009.

[10] R.J. Albertini, D. Anderson, G.R. Douglas, L. Hagmar, K. Hemminki, F. Merlo, A.T. Natarajan, H. Norppa, D.E. Shuker, R. Tice, M.D. Waters, A. Aitio, IPCS guidelines for the monitoring of genotoxic effects of carcinogens in humans. International Programme on Chemical Safety, Mutat. Res. 463 (2) (2000) 111-172.

[11] S. Bonassi, A. Znaor, M. Ceppi, C. Lando, W.P. Chang, N. Holland, M. KirschVolders, E. Zeiger, S. Ban, R. Barale, M.P. Bigatti, C. Bolognesi, A. CebulskaWasilewska, E. Fabianova, A. Fucic, L. Hagmar, G. Joksic, A. Martelli, L. Migliore, E. Mirkova, M.R. Scarfi, A. Zijno, H. Norppa, M. Fenech, An increased micronucleus frequency in peripheral blood lymphocytes predicts the risk of cancer in humans, Carcinogenesis 28 (3) (2007) 625-631.

[12] E. Murgia, M. Ballardin, S. Bonassi, A.M. Rossi, R. Barale, Validation of micronuclei frequency in peripheral blood lymphocytes as early cancer risk biomarker in a nested case-control study, Mutat. Res. 639 (1-2) (2008) 27-34.

[13] J.T. Cohen, G. Carlson, G. Charnley, D. Coggon, E. Delzell, J.D. Graham, H. Greim, D. Krewski, M. Medinsky, R. Monson, D. Paustenbach, B. Petersen, S. Rappaport, L. Rhomberg, P.B. Ryan, K. Thompson, A comprehensive evaluation of the potential health risks associated with occupational and environmental exposure to styrene, J. Toxicol. Environ. Health B Crit. Rev. 5 (1-2) (2002) 1263.

[14] M. Somorovská, E. Jahnová, J. Tulinská, M. Zámecníková, J. Sarmanová, A. Terenová, L. Vodicková, A. Lísková, B. Vallová, P. Soucek, K. Hemminki, H. Norppa, A. Hirvonen, A.D. Tates, L. Fuortes, M. Dusinská, P. Vodicka, Biomonitoring of occupational exposure to styrene in a plastics lamination plant, Mutat. Res. 16 (428(1-2)) (1999) 255-269.

[15] S. Bonassi, F. Montanaro, M. Ceppi, A. Abbondandolo, Is human exposure to styrene a cause of cytogenetic damage?: A re-analysis of the available evidence, Biomarkers 1 (1996) 217-225.

[16] L.M. Henderson, G. Speit, Review of the genotoxicity of styrene in humans, Mutat. Res. 589 (3) (2005) 158-191. 
[17] D. Moher, A. Liberati, J. Tetzlaff, Preferred reporting items for systematic reviews and meta-analyses: the PRISMA statement, Br. Med. J. 339 (2009) 332 338.

[18] R. DerSimonian, N. Laird, Meta-analysis in clinical trials, Contr. Clin. Trials 7 (1986) 177-188.

[19] M. Egger, J.D. Smith, M. Schneider, C. Minder, Bias in meta-analysis detected by a simple, graphical test, BMJ 315 (1997) 629-634.

[20] StataCorp, Stata Statistical Sofware: Release 13, StataCorp LP, College Station, TX, 2013.

[21] P. Van Hummelen, M. Severi, W. Pauwels, D. Roosels, H. Veulemans, M. KirschVolders, Cytogenetic analysis of lymphocytes from fiberglass-reinforced plastics workers occupationally exposed to styrene, Mutat. Res. 310 (1) (1994) 157-165.

[22] J. Mäki-Paakkanen, S. Walles, S. Osterman-Golkar, H. Norppa, Single-strand breaks, chromosome aberrations, sister-chromatid exchanges, and micronuclei in blood lymphocytes of workers exposed to styrene during the production of reinforced plastics, Environ. Mol. Mutagen. 17 (1) (1991) 27-31.

[23] J.W. Yager, W.M. Paradisin, S.M. Rappaport, Sister-chromatid exchanges in lymphocytes are increased in relation to longitudinally measured occupational exposure to low concentrations of styrene, Mutat. Res. 319 (3) (1993) 155-165.

[24] A.D. Tates, T. Grummt, F.J. van Dam, F. de Zwart, F.J. Kasper, R. Rothe, H. Stirn, A H. Zwinderman, A.T. Natarajan, Measurement of frequencies of HPRT mutants chromosomal aberrations, micronuclei, sister-chromatid exchanges and cells withhigh frequencies of SCEs in styrene/dichloromethane-exposed workers, Mutat. Res. 313 (2-3) (1994) 249-262.

[25] O. Holz, G. Scherer, S. Brodtmeier, F. Koops, K. Warncke, T. Krause, A. Austen, J. Angerer, A.R. Tricker, F. Adlkofer, Determination of low level exposure to volatile aromatic hydrocarbons and genotoxic effects in workers at a styrene plant, Occup. Environ. Med. 52 (6) (1995) 420-428.

[26] R. Tomanin, C. Ballarin, G.B. Bartolucci, E. De Rosa, G. Sessa, G. Iannini, A.R. Cupiraggi, F. Sarto, Chromosome aberrations and micronuclei in lymphocytes of workers exposed to low and medium levels of styrene, Int. Arch. Occup. Environ. Health 64 (3) (1992) 209-215.

[27] W.A. Anwar, M.Y. Shamy, Chromosomal aberrations and micronuclei in reinforced plastics workers exposed to styrene? Mutat. Res. 327 (1-2) (1995) 41-47.

[28] B. Laffon, E. Pásaro, J. Méndez, Evaluation of genotoxic effects in a group of workers exposed to low levels of styrene? Toxicology 171 (2-3) (2002) 175186.

[29] P. Vodicka, J. Tuimala, R. Stetina, R. Kumar, P. Manini, A. Naccarati, L. Maestri, L. Vodickova, M. Kuricova, H. Järventaus, Z. Majvaldova, A. Hirvonen, M. Imbriani, A. Mutti, L. Migliore, H. Norppa, K. Hemminki, Cytogenetic markers, DNA single-strand breaks, urinary metabolites, and DNA repair rates in styreneexposed lamination workers, Environ. Health Perspect. 112 (8) (2004) 867871.

[30] L. Godderis, M. De Boeck, V. Haufroid, M. Emmery, R. Mateuca, S. Gardinal, M. Kirsch-Volders, H. Veulemans, D. Lison, Influence of genetic polymorphisms on biomarkers of exposure and genotoxic effects in styrene-exposed workers, Environ. Mol. Mutagen. 44 (4) (2004) 293-303.

[31] J.P. Teixeira, J. Gaspar, S. Silva, J. Torres, S.N. Silva, M.C. Azevedo, P. Neves, B. Laffon, J. Méndez, C. Gonçalves, O. Mayan, P.B. Farmer, J. Rueff, Occupational exposure to styrene: modulation of cytogenetic damage and levels of urinary metabolites of styrene by polymorphisms in genes CYP2E1, EPHX1, GSTM1, GSTT1 and GSTP1, Toxicology 195 (2-3) (2004) 231-242.

[32] L. Migliore, A. Naccarati, F. Coppedè, E. Bergamaschi, G. De Palma, A. Voho, P. Manini, H. Järventaus, A. Mutti, H. Norppa, A. Hirvonen, Cytogenetic biomarkers, urinary metabolites and metabolic gene polymorphisms in workers exposed to styrene, Pharmacogenet. Genomics 16 (2) (2006) 87-99.

[33] L. Migliore, R. Colognato, A. Naccarati, E. Bergamaschi, Relationship between genotoxicity biomarkers in somatic and germ cells: findings from a biomonitoring study, Mutagenesis 21 (2) (2006) 149-152.

[34] M. Hanova, R. Stetina, L. Vodickova, R. Vaclavikova, P. Hlavac, Z. Smerhovsky, A. Naccarati, V. Polakova, P. Soucek, M. Kuricova, P. Manini, R. Kumar, K. Hemminki, P. Vodicka, Modulation of DNA repair capacity and mRNA expression levels of XRCC1, hOGG1 and XPC genes in styrene-exposed workers, Toxicol. Appl. Pharmacol. 248 (3) (2010) 194-200.

[35] J.P. Teixeira, J. Gaspar, P. Coelho, C. Costa, S. Pinho-Silva, S. Costa, S. Da Silva, B. Laffon, E. Pásaro, J. Rueff, P. Farmer, Cytogenetic and DNA damage on workers exposed to styrene, Mutagenesis 5 (6) (2010) 617-621.

[36] C. Costa, S. Costa, S. Silva, P. Coelho, M. Botelho, J. Gaspar, J. Rueff, B. Laffon, J.P. Teixeira, DNA damage and susceptibility assessment in industrial workers exposed to styrene? J. Toxicol. Environ. Health A 75 (13-15) (2012) 735-746.

[37] ACGIH ${ }^{\mathrm{B}}$, TLV's and BEI's - Based on the Documentation of the Threshold Limit Values for Chemical Substances and Physical Agents and Biological Exposure Indices, ACGIH (American Conference of Governmental Industrial Hygienists), 2015 (254 pp.).

[38] ACGIH ${ }^{\mathbb{R}}$, TLV's and BEI's - Based on the Documentation of the Threshold Limit Values for Chemical Substances and Physical Agents and Biological Exposure Indices, ACGIH (American Conference of Governmental Industrial Hygienists), 2002 (187 pp.).

[39] M. Fenech, A.A. Morley, Measurement of micronuclei in lymphocytes? Mutat. Res. 147 (1-2) (1985) 29-36.

[40] S. Bonassi, M. Neri, C. Lando, M. Ceppi, Y.P. Lin, W.P. Chang, N. Holland, M. Kirsch-Volders, E. Zeiger, M. Fenech, HUMN collaborative group, Effect of smoking habit on the frequency of micronuclei in human lymphocytes: results from the Human MicroNucleus project, Mutat. Res. 543 (2) (1991) $155-166$.

[41] M. Fenech, The cytokinesis-block micronucleus technique and its application to genotoxicity studies in human populations, Environ. Health Perspect. 101 (1993) 101-107.

[42] M. Kirsch-Volders, T. Sofuni, M. Aardema, S. Albertini, D. Eastmond, M. Fenech, M. Ishidate Jr, E. Lorge, H. Norppa, J. Surrallés, W. von der Hude, A. Wakata, Report from the In vitro micronucleus assay working group, Environ. Mol. Mutagen. 35 (3) (2000) 167-172.

[43] H. Caria, T. Chaveca, A. Laires, J. Rueff, Genotoxicity of quercetin in the micronucleus assay in mouse bone marrow erythrocytes human lymphocytes, V79 cell line and identification of kinetochore-containing (CREST staining) micronuclei in human lymphocytes, Mutat. Res. 343 (2-3) (1995) 85-94.

[44] R. Tomanin, C. Ballarin, B. Nardini, G. Mastrangelo, F. Sarto, Influence of smoking habit on the frequency of micronuclei in human lymphocytes by the cytokinesis block method, Mutagenesis 6 (2) (1991) 123-126.

[45] S. Bonassi, M. Fenech, C. Lando, Y.P. Lin, M. Ceppi, W.P. Chang, N. Holland, M Kirsch-Volders, E. Zeiger, S. Ban, R. Barale, M.P. Bigatti, C. Bolognesi, C. Jia, M. Di Giorgio, L.R. Ferguson, A. Fucic, O.G. Lima, P. Hrelia, A.P. Krishnaja, T.K. Lee, L. Migliore, L. Mikhalevich, E. Mirkova, P. Mosesso, W.U. Müller, Y. Odagiri, M.R. Scarffi, E. Szabova, I. Vorobtsova, A. Vral, A. Zijno, HUman MicroNucleus project: international database comparison for results with the cytokinesisblock micronucleus assay in human lymphocytes: I. Effect of laboratory protocol, scoring criteria, and host factors on the frequency of micronuclei, Environ. Mol. Mutagen. 37 (1) (2001) 31-45.

[46] M. Fenech, W.P. Chang, M. Kirsch-Volders, N. Holland, S. Bonassi, E. Zeiger, Human MicronNucleus project.. HUMN project: detailed description of the scoring criteria for the cytokinesis-block micronucleus assay using isolated human lymphocyte cultures, Mutat. Res. 534 (1-2) (2003) 65-75.

[47] L. Hagmar, B. Högstedt, H. Welinder, A. Karlsson, F. Rassner, Cytogenetic and hematological effects in plastics workers exposed to styrene, Scand. J. Work. Environ. Health 15 (2) (1989) 136-141.

[48] A.E. Karakaya, B. Karahalil, M. Yilmazer, N. Aygün, S. Sardaș, S. Burgaz, Evaluation of genotoxic potential of styrene in furniture workers using unsaturated polyester resins, Mutat. Res. 392 (3) (1997) 261-268.

[49] D.D. Brenner, A.M. Jeffrey, L. Latriano, L. Wazneh, D. Warburton, M. Toor, R.W. Pero, L.R. Andrews, S. Walles, F.P. Perera, Biomarkers in styrene-exposed boatbuilders, Mutat. Res. 261 (3) (1991) 225-236.

[50] B. Högstedt, B. Akesson, K. Axell, B. Gullberg, F. Mitelman, R.W. Pero, S. Skerfving, H. Welinder, Increased frequency of lymphocyte micronuclei in workers producing reinforced polyester resin with low exposure to styrene, Scand. J. Work Environ. Health 9 (3) (1983) 241-246.

[51] R.C. Bonanni, M.P. Gatto, E. Paci, A. Gordiani, M. Gherardi, G. Tranfo, Biomonitoring for exposure assessment to styrene in the fibreglass reinforced plastic industry: determinants and interferents, Ann. Occup. Hyg. 59 (8) (2015) 1000-1011.

[52] D. Scott, R.J. Preston, A re-evaluation of the cytogenetic effects of styrene, Mutat. Res. 318 (3) (1994) 175-203.

[53] J. Surrallés, A. Antoccia, A. Creus, F. Degrassi, F. Peris, C. Tanzarella, N. Xamena, R. Marcos, The effect of cytochalasin-B concentration on the frequency of micronuclei induced by four standard mutagens. Results from two laboratories, Mutagenesis 9 (4) (1994) 347-353.

[54] M. Fenech, Cytokinesis-block micronucleus cytome assay, Nat. Protoc. 2 (5) (2007) 1084-1104.

[55] P. Vodicka, M. Koskinen, A. Naccarati, B. Oesch-Bartlomowicz, L. Vodickova, K. Hemminki, F. Oesch, Styrene metabolism, genotoxicity, and potential carcinogenicity, Drug Metab. Rev. 38 (4) (2006) 805-853.

[56] B. Laffon, E. Pásaro, J. Méndez, Effects of styrene-7,8-oxide over p53, p21, bcl-2 and bax expression in human lymphocyte cultures, Mutagenesis 16 (2) (2001) $127-132$.

[57] B. Marczynski, P. Rozynek, H.J. Elliehausen, M. Korn, X. Baur, Detection of 8hydroxydeoxyguanosine, a marker of oxidative DNA damage, in white blood cells of workers occupationally exposed to styrene, Arch. Toxicol. 71 (8) (1997) 496-500.

[58] P. Vodicka, L. Vodicková, K. Trejbalová, R.J. Srám, K. Hemminki, Persistence of O6-guanine DNA adducts in styrene-exposed lamination workers determined by 32P-postlabelling, Carcinogenesis 15 (9) (1994) 1949-1953.

[59] M. Koskinen, P. Vodicka, K. Hemminki, Identification of 1-adenine DNA adducts in workers occupationally exposed to styrene, J. Occup. Environ. Med. 43 (8) (2001) 694-700.

[60] B. Laffon, E. Pásaro, J. Méndez, Genotoxic effects of styrene-7,8-oxide in human white blood cells: comet assay in relation to the induction of sister-chromatid exchanges and micronuclei? Mutat. Res. 491 (1-2) (2001) 163-172.

[61] T. Bastlová, P. Vodièka, K. Peterková, K. Hemminki, B. Lambert, Styrene oxideinduced HPRT mutations, DNA adducts and DNA strand breaks in cultured human lymphocytes, Carcinogenesis 16 (10) (1995) 2357-2362.

[62] M.E. Fracasso, D. Doria, M. Carrieri, G.B. Bartolucci, S. Quintavalle, E. De Rosa DNA single- and double-strand breaks by alkaline- and immuno-comet assay in lymphocytes of workers exposed to styrene, Toxicol. Lett. 185 (1) (2009) 915.

[63] D.M. Wilson, L.H. Thompson 3rd, Molecular mechanisms of sister-chromatid exchange? Mutat. Res. 616 (1-2) (2007) 11-23. 
[64] B. Laffon, B. Pérez-Cadahía, E. Pásaro, J. Méndez, Effect of epoxide hydrolase and glutathione S-tranferase genotypes on the induction of micronuclei and DNA damage by styrene-7,8-oxide in vitro, Mutat. Res. 536 (2003) 49-59.

[65] B. Laffon, B. Pérez-Cadahía, E. Pásaro, J. Méndez, Individual sensitivity to DNA damage induced by styrene in vitro: influence of cytochrome P450, epoxide hydrolase and glutathione S-transferase genotypes, Toxicology 186 (2003) 131-141.

[66] P. Vodicka, P. Soucek, A.D. Tates, M. Dusinska, J. Sarmanova, M. Zamecnikova, L. Vodickova, M. Koskinen, F.A. de Zwart, A.T. Natarajan, K. Hemminki, Association between genetic polymorphism and biomarkers in styreneexposed workers, Mutat. Res. 482 (2001) 89-103.
[67] J. Rueff, J.P. Teixeira, L.S. Santos, J.F. Gaspar, Genetic effects and biotoxicity monitoring of occupational styrene exposure? Clin. Chim. Acta 399 (1-2) (2009) 8-23.

[68] S. Wongvijitsuk, P. Navasumrit, U. Vattanasit, V. Parnlob, M. Ruchirawat, Low level occupational exposure to styrene: its effects on DNA damage and DNA repair, Int. J. Hyg. Environ. Health 214 (2) (2011) 127-137.

[69] J. Sarmanová, L. Týnková, S. Süsová, I. Gut, P. Soucek, Genetic polymorphisms of biotransformation enzymes: allele frequencies in the population of the Czech Republic, Pharmacogenetics 10 (2000) 781-788. 